\title{
Beden Eğitimi ve Spor Öğretmenlerinin Aldıkları Hizmet Öncesi Eğitime İlişkin
}

ISSN: 2536-5339

\section{Algılarının Belirlenmesi
ŏitimi ve Spor Öğretmenlerinin Aldıkları Hizme}

\author{
Ahmet Enes SAĞIN ${ }^{1 *}$ (D) \\ ${ }^{1}$ İnönü Üniversitesi, Spor Bilimleri Fakültesi, MALATYA \\ ${ }^{2}$ Bağcilar Piri Reis Ortaokulu, MEB, ISTANBUL
}

Ömer KARABULUT ${ }^{2}$

DOI: 10.31680/gaunjss.728004

Orijinal Makale / Original Article

Geliş Tarihi / Received: 27.04.2020

Kabul Tarihi / Accepted: 21.05.2020

Yayın Tarihi / Published: 15.06.2020

\section{Öz}

Bu araştırmada beden eğitimi ve spor öğretmenlerinin aldıkları hizmet öncesi eğitime ilişkin algılarının belirlenmesi amaçlanmıştır. Kozikoğlu ve Senemoğlu (2018) tarafından geliştirilen 25 maddeden oluşan "Hizmet Öncesi Eğitimin Yeterliğine ilişkin Öğretmen Algı Ölçeğı" kullanılmıştır. Ölçekte "öğretimi planlama ve uygulama" ve "öğrenci, meslektaş, yönetici, veli ve toplumla ilişkiler" adında 2 alt boyut yer almaktadır. Tarama modelinde gerçekleştirilmiş olan çalışmada araştırma grubunu İstanbul il ve ilçelerinde görev yapan 158 beden eğitimi ve spor öğretmeni oluşturmaktadır. Elde edilen veriler normal dağıım gösterdiğinden verilerin analizinde betimsel istatistiklerle birlikte İndepentendent Sample $t$ testi ve One Way Anova tercih edilmiştir. Beden eğitimi öğretmenlerinin hizmet öncesi eğitime ilişkin algıları yeterli düzeyde olmamakla birlikte, cinsiyet, mesleki deneyimi, mezun oldukları müfredat programı değişkenlerinde istatistiksel olarak anlamlı bir fark göstermediği tespit edilmiştir. Beden eğitimi öğretmenleri mesleki hayatlarına başlamadan önce almış oldukları hizmet öncesi eğitimin özellikle "öğretimi planlama ve uygulama" boyutunda yeterli olmadığına dair bir algıya sahiptir. Beden eğitimi ve spor öğretmenleri eğitim ortamının düzenlenmesi, materyal hazırlama, konu alanı ve öğretim programı bilgisi, öğretme ve öğrenme etkinliklerinin uygulanması, sınıf yönetimi ve ölçme değerlendirme noktasında almış oldukları eğitimi yeterli görmemektedir.

Anahtar Kelimeler: Hizmet öncesi eğitim, Öğretmen eğitimi, Lisans eğitimi

\section{Determination of the Perceptions of Physical Education and Sport Teachers About Pre-Service Education}

\begin{abstract}
In this study, it was aimed to determine the perceptions of physical education and sports teachers about preservice education. It includes a "Teacher Perception Scale according to the Adequacy of Pre-Service Education" which consists of 25 items made by Kozikoğlu and Senemoğlu (2018).The scale has two sub-dimensions called planlama planning and practicing teaching ve and öğrenci relations with students, colleagues, administrators, parents and society ". In the study which was carried out in the screening model, 158 physical education and sports teachers working in Istanbul provinces and districts constitute the research group. Since the data obtained showed normal distribution, Independent Samples T-Test and One-Way Analysis of Variance (ANOVA) were preferred with descriptive statistics. Physical education teachers ' perceptions of pre-service education were not sufficient, but they showed no statistically significant difference in gender, professional experience, and graduation year variables. Physical education teachers have a perception that the pre-service education they received before they started their professional lives is not sufficient, especially in the "planning and implementation of teaching" dimension. Physical education and sports teachers think that the undergraduate education that they have received is not adequate on the points of; regulation of the educational environment, material preparation, subject areas, and knowledge of curriculum, implementation of teaching and learning activities, classroom management and assessment.
\end{abstract}

Keywords: Pre-service education, Teacher training, Undergraduate education

\footnotetext{
* Sorumlu Yazar: Ahmet Enes SAĞIN

E-mail: a.e.sagin@outlook.com

Bu çalışma 24-26 Ekim 2019 tarihlerinde 3. International Health Sciences Congress'nde sözel bildiri olarak sunulmuştur.
} 


\section{Giriş}

Eğitim, bireyin davranışlarında öz yaşantısı vasıtasıyla ve tasarlanmış bir biçimde istendik değişimler oluşturma sürecidir. Bu süreçte davranış değişikliği kişinin kendisinde ortaya çıksa da değişikliğin meydana gelmesinde bir yol gösterici ihtiyacı vardır. Bireylerin alakaları ve intiyaçları doğrultusunda yol gösterecek kişi ise öğretmendir (Gökmen, 1988). Öğretmen bu süreçteki en etkili etkenlerden birisidir ve eğitim ekolünün niteliğini belirleyici unsurların başında gelir (Doğan ve Koçak, 2014). Öğretmenin kalitesinin gelişiminde de hali hazırda uygulanan eğitim politikaları belirleyici rol oynamaktadır. Bu bağlamda bakacak olursak öğretmen yetiştiren kurumlar bünyesinde intiyaç duyulan yetkinliğe haiz kalifiye öğretmenler yetiştirilmelidir (Senemoğlu, 1990). Öğretmen yetiştiren kurumların kalitesi, güncelliği, tesis ve donanımı, yürürlükteki programın içeriği, kurumdaki eğitimcilerin niteliği de bu eğitim kurumundan mezun öğretmenlerin niteliğini direkt olarak etkiler (Uğraş ve Güllü, 2019).

Beden eğitimi bireyin hareket edebilme becerisini öğrenmesi ve bir bakıma fiziksel aktiviteleri planlı yapması ve yaşam stiline dönüştürmesi biçiminde tanımlanabilir (Nebioğlu, 2006). Bu açıdan yaklaşıldığında bir beden eğitimi öğretmeninde alan bilgisi ve yeteneğinin olması, sportif olması, dış görünüşünün iyi olması, kişilerarası ilişkilerinin gelişmiş olması, kritik yapabilmesi, iyi bir düzen anlayışına sahip olması, spor yapmaya ilgi uyandırması gibi birtakım özellikler sıralanabilir (Demirhan, 2003; Friedman, 1983). Beden eğitimi; bireyin fiziki yapısını geliştirmesi ve genel sağlığını muhafaza etmesinin yanı sıra bireyin düşünmesini sağlayarak biyolojik yapısını tanımasını olanaklı kılar (Aracı, 2001). Bütün bu özellikleri kazandırması açısından hizmet öncesi öğretmen eğitimi önem göstermektedir.

Hizmet öncesi öğretmen eğitimi, öğretmenlerin alanlarındaki ilerleyiş aşamasında hayati bir bileşendir ki; adayların etkili öğretim amacıyla ihtiyaç duyduğu konu alanı bilgisi, alana dair yaklaşım ve yeteneklerle donatmaktadır. Hizmet öncesi eğitimin iyi olması öğretmenleri alanda muhafaza etmeyi ve onları güdülemeyi sağlayacaktır (Lim, Cock, Lock ve Brock, 2009). Ülkemizde öğretmen yetiştirme ile ilgili olarak 1980'li yıllardan sonra önemli adımlar atılmıştır. 1981 yılında 2547 sayılı yükseköğretim kanunu çıkarılmış bu kanun kapsamında eğitim fakülteleri kurulmuştur. Spor akademileri de bölüm olarak eğitim fakültelerinin bünyesine alınmıştır (Demirhan ve Açıkada, 1997). 1998 yılında YÖK almış olduğu karar ile 
beden eğitimi öğretmenliği lisans programını her üniversitenin kendi hazırlaması yerine merkezi hazırlanan bir program çerçevesinde yürütülmesine karar vermiştir. 2006 yılında ise bu program revize edilmiş ve günümüzde ise hala kullanılmaya devam edilmektedir. Bu programlar çerçevesinde üniversitelerde uygulanan hizmet öncesi eğitimin niteliği sürekli tartışma konusu olmuş bununla ilgili doğrudan ve dolaylı olarak çalışmalar yapılmıştır.

Bulca, Saçlı, Kangalgil ve Demirhan (2012) okullarda okutulan beden eğitimi ve spor ders içeriğiyle beden eğimi ve spor öğretmenliği programlarının paralellik göstermesi gerektiğini vurgulamaktadır. Ancak ülkemizde yapılan çalışmalarda beden eğitimi spor bölümlerinde verilen lisans eğitimiyle MEB'e bağlı okulların imkan ve şartlarına göre beden eğitimi ve spor öğretmeni yetişmediği (Uğraş ve Güllü, 2019), mevcut lisans programının ihtiyaçları karşılamadığı ve özellikle alan bilgisi noktasında uygulamanın artırılması gerektiği belirtilmektedir (Kızılkaya, 2018). Yurt dışında yapılan çalışmalarda ise beden eğitimi ve spor lisans programlarının güncelleştirilmesi gerektiği noktasında ortak görüş olmasına rağmen bazıları; üniversitede programlarının merkezinde performansın olması gerektiği beceri odaklı bir lisans eğitiminin öğretmen adaylarına verilerek okullarda öğretileceklerinden çok daha geniş kapsamlı bir hareket becerisi edinmeleri konusunda ısrar edilmesi gerektiğini ileri sürmektedir (Siedentop, 2002). Bu görüşün aksine Kirk, (1990) performans odaklı bir programı desteklememektedir. Fernández-Balboa ise (1997) gelecekte beden eğitimi derslerinde çalışmanın ana çekirdeğini geleneksel sınıf yönetimi, kontrol stratejileri, öğretimi planlama ve organize etme temel ilkelerinin oluşturacağını belirtilmektedir.

Genel olarak yurtiçi ve yurtdışında yapılan çalışmalarda beden eğitimi ve spor lisans programlarının istenilen nitelikte olmadığı yönündedir. Bu çalışmada da beden eğitimi ve spor bölümlerinden mezun olan MEB'e bağlı okullarda mesleki hayatlarını sürdüren beden eğitimi öğretmenlerin görüşlerine başvurularak, almış oldukları lisans programlarından memnuniyet düzeylerinin belirlenmesi amaçlanmıştır.

\section{Yöntem}

\section{Araştırmanın Modeli}

Bu araştırmada beden eğitimi ve spor öğretmenlerinin aldıkları hizmet öncesi eğitime ilişkin algılarının belirlenmesi amaçlanmıştır. Dolayısıyla araştırma yöntem olarak betimlemeye yöneliktir. Betimsel araştırmalar Karasar'a (2009) göre olayların, 
Sağın AE, Karabulut Ö. (2020). Beden Eğitimi ve Spor Öğretmenlerinin Aldıkları Hizmet Öncesi Eğitime İlişkin Algılarının Belirlenmesi. Gaziantep Üniversitesi Spor Bilimleri Dergisi, 5(2), 121-133.

kurumların, varlıkların, objelerin ve farklı alanların ne olduğunu betimleyip açıklamaya çalışan çalışmalardır.

\section{Araştırma Grubu}

Araştırmanın çalışma grubunu İstanbul il ve ilçelerinde görev yapan 190 beden eğitimi ve spor öğretmeni oluşturmaktadır. Çalışmada örnekleme yöntemi olarak; "tesadüfi (basit rastlanstısal) örnekleme" seçilmiştir. Bu yöntemde evren içerisinde yer alan bireyler eşit düzeyde seçilme şansına sahiptir (Balcı, 2018; Karasar, 2012). Araştırmaya katılan beden eğitimi ve spor öğretmenlerinin nitelikleri tablo 1'de verilmiştir.

Tablo 1.Beden eğitimi öğretmenlerinin sosyo-demografik özellikleri

\begin{tabular}{lll}
\hline Cinsiyet & Sayı (n) & Yüzde (\%) \\
Erkek & 141 & $\% 79,2$ \\
Kadın & 37 & $\% 20,8$ \\
Toplam & 178 & $\% 100$ \\
\hline Meslekte deneyim yılı & Sayı (n) & Yüzde (\%) \\
$1-5$ yıl & 68 & $\% 38,2$ \\
$6-10$ yıl & 67 & $\% 37,6$ \\
$11-15$ yıl & 25 & $\% 14,0$ \\
16 ve üzeri & 18 & $\% 10,1$ \\
Toplam & 178 & $\% 100$ \\
\hline Mezuniyet programı & Sayı (n) & Yüzde (\%) \\
2006 programı öncesi & 54 & $\% 30,3$ \\
2006 programı sonrası & 124 & $\% 68,7$ \\
Toplam & 178 & $\% 100$ \\
\hline
\end{tabular}

\section{Verilerin Toplanması}

Araştırmada veri toplama aracı olarak Kozikoğlu ve Senemoğlu (2018) tarafından geliştirilen 25 maddeden oluşan "Hizmet Öncesi Eğitimin Yeterliğine ilişkin Öğretmen Algı Ölçeği” kullanılmıştır. Ölçek 25 maddeden ve "öğretimi planlama ve uygulama" ve "öğrenci, meslektaş, yönetici, veli ve toplumla ilişkiler" adında 2 alt boyuttan meydana gelmektedir. Ölçek maddeleri "Yetersiz" (1), "Düşük düzeyde" (2), "Orta düzeyde" (3), “İyi düzeyde” (4), “Çok iyi düzeyde” (5) şeklinde 5’li likert tipindedir. Ölçekten alınabilecek puan aralığı 25-125 arasındadır. Puanların yükselmesi katılımcıların hizmet öncesi eğitimeilişkin algılarının yüksek düzeyde olduğunu göstermektedir. Ölçeğin 2 faktörlü yapısını oluşturan olan boyutların cronbachalpha değerleri sırasıyla öğretimi planlama ve uygulama .939 öğrenci, meslektaş, yönetici, veli ve toplumla ilişkiler .913 çıkmıştır. 


\section{Verilerin analizi}

Araştırmada 190 beden eğitimi ve spor öğretmenine uygulanan ölçekte anlamsız veya eksik olan 12 anket çalışmadan çıkarılmıştır. Araştırma sonucunda elde edilen verilerin analizinde SPSS paket programından faydalanılmıştır. Öncelikle verilerin normal dağılıp dağılmadığını test etmek amacıyla çarpıklık ve basıklık değerlerine bakılmıştır (Tablo 2). Bu değerlerin +1,5 ile -1,5 arasında kalmasından parametrik testler tercih edilmiştir (Tabachnick, Fidell ve Ullman, 2013; Hair, Black, Babin, Anderson ve Tatham, 2013). Verilerin analizinde Indepentendent Sample t testi ve OneWayAnova testi kullanılmıştır.

Tablo 2. Çarpıklık ve basıklık değerleri

\begin{tabular}{lcc}
\hline Alt Boyutlar & Çarpıklık & Basıklık \\
\hline Öğretimi planlama ve uygulama & -637 & $-1,134$ \\
Öğrenci, meslektaş, yönetici, veli ve &,- 533 &,- 863 \\
toplumla ilişkiler &,- 632 & $-1,143$ \\
Toplam & & \\
\hline
\end{tabular}

\section{Bulgular}

Tablo 3. Beden eğitimi ve spor öğretmenlerinin cinsiyet değişkenine göre İndependent Sample T Testi Sonuçları

\begin{tabular}{|c|c|c|c|c|c|c|}
\hline Alt Boyutlar & Cinsiyet & $n$ & $\overline{\mathbf{x}}$ & ss & $t$ & $\mathbf{p}$ \\
\hline \multirow{2}{*}{$\begin{array}{l}\text { Öğretimi planlama } \\
\text { ve uygulama }\end{array}$} & Erkek & 141 & 3,024 & 1,143 & \multirow{2}{*}{,821 } & \multirow{2}{*}{, 415 } \\
\hline & Kadın & 37 & 2,856 & 1,101 & & \\
\hline \multirow{2}{*}{$\begin{array}{l}\text { Öğrenci, } \\
\text { meslektaş, } \\
\text { yönetici, veli ve } \\
\text { toplumla ilişkiler }\end{array}$} & Erkek & 141 & 3,384 & 1,097 & \multirow[b]{2}{*}{,337 } & \multirow[b]{2}{*}{,738 } \\
\hline & Kadın & 37 & 3,303 & 1,356 & & \\
\hline \multirow{2}{*}{ Toplam } & Erkek & 141 & 3,154 & 1,096 & \multirow{2}{*}{ 651 } & \multirow{2}{*}{,518 } \\
\hline & Kadın & 37 & 3,017 & 1,150 & & \\
\hline
\end{tabular}

Tablo 3' de beden eğitimi ve spor öğretmenlerinin hizmet öncesi eğitime ilişkin algıları cinsiyet değişkenine göre karşılaştırılmıştır. Test sonuçlarına göre öğretimi planlama ve uygulama boyutunda $\mathrm{t}=.821, \mathrm{p}=.415$ öğrenci, meslektaş, yönetici, veli ve toplumla ilişkiler boyutunda $t=.337, p=.738$ ve toplamda $t=.651, p=.518$ olarak belirlenmiştir. Katılımcıların hizmet öncesi eğitime ilişkin algılarında cinsiyet değişkenine göre anlamlı fark bulunmamıştır. 
Tablo 4. Beden eğitimi ve spor öğretmenlerinin mezun oldukları müfredat programı değişkenine göre İndependent Sample T Testi sonuçları

\begin{tabular}{|c|c|c|c|c|c|c|c|}
\hline Alt Boyutlar & $\begin{array}{l}\text { Mezunis } \\
\text { progran }\end{array}$ & & $\mathbf{n}$ & $\overline{\mathbf{x}}$ & ss & $\mathbf{t}$ & p \\
\hline \multirow{2}{*}{$\begin{array}{l}\text { Öğretimi planlama } \\
\text { ve uygulama }\end{array}$} & $\begin{array}{l}2006 \\
\text { öncesi }\end{array}$ & & 54 & 2,925 & 1,183 & \multirow[b]{2}{*}{,- 484} & \multirow[b]{2}{*}{,630 } \\
\hline & $\begin{array}{l}2006 \\
\text { sonrası }\end{array}$ & programı & 124 & 3,017 & 1,115 & & \\
\hline \multirow{2}{*}{$\begin{array}{l}\text { Öğrenci, } \\
\text { meslektaş, } \\
\text { yönetici, veli ve } \\
\text { toplumla ilişkiler }\end{array}$} & $\begin{array}{l}2006 \\
\text { öncesi }\end{array}$ & & 54 & 3,432 & 1,029 & \multirow{2}{*}{, 523} & \multirow[b]{2}{*}{,602 } \\
\hline & $\begin{array}{l}2006 \\
\text { sonrası }\end{array}$ & programı & 124 & 3,339 & 1,205 & & \\
\hline \multirow{2}{*}{ Toplam } & $\begin{array}{l}2006 \\
\text { öncesi }\end{array}$ & & 54 & 3,108 & 1,092 & \multirow{2}{*}{,- 142} & \multirow{2}{*}{,888 } \\
\hline & $\begin{array}{l}2006 \\
\text { sonrası }\end{array}$ & programı & 124 & 3,133 & 1,116 & & \\
\hline
\end{tabular}

Tablo 4 incelendiğinde 2006 programı öncesinde mezun olan öğretmenler ile 2006 programı sonrasında mezun olan öğretmenler arasında istatistiksel olarak anlamlı bir fark belirlenmemiştir. Test sonuçlarına göre öğretimi planlama ve uygulama boyutunda $\mathrm{t}=-.484, \mathrm{p}=.630$ öğrenci, meslektaş, yönetici, veli ve toplumla ilişkiler boyutunda $\mathrm{t}=.523, \mathrm{p}=.602 \mathrm{ve}$ toplamda $\mathrm{t}=-.142, \mathrm{p}=.518$ olarak tespit edilmiştir.

Tablo 5. Beden eğitimi ve spor öğretmenlerinin mesleki deneyim değişkenine göre One Way Anova Testi sonuçları

\begin{tabular}{|c|c|c|c|c|c|c|}
\hline Alt Boyutlar & $\begin{array}{l}\text { Mesleki } \\
\text { deneyim }\end{array}$ & $\mathbf{n}$ & $\overline{\mathbf{x}}$ & ss & $f$ & p \\
\hline \multirow{4}{*}{$\begin{array}{l}\text { Öğretimi planlama ve } \\
\text { uygulama }\end{array}$} & $1-5 \mathrm{yll}$ & 68 & 3,068 & 1,147 & \multirow{4}{*}{1,37} & \multirow{4}{*}{,253 } \\
\hline & 6-10 yıl & 67 & 2,942 & 1,091 & & \\
\hline & $11-15 \mathrm{yll}$ & 25 & 2,662 & 1,268 & & \\
\hline & 16 ve üzeri & 18 & 3.322 & ,994 & & \\
\hline \multirow{4}{*}{$\begin{array}{l}\text { Öğrenci, meslektaş, } \\
\text { yönetici, veli ve toplumla } \\
\text { ilişsiler }\end{array}$} & $1-5 \mathrm{yll}$ & 68 & 3,482 & 1,274 & \multirow{4}{*}{1,17} & \multirow{4}{*}{,322 } \\
\hline & 6-10 yıl & 67 & 3,240 & 1,112 & & \\
\hline & $11-15 \mathrm{yll}$ & 25 & 3,173 & 1,162 & & \\
\hline & 16 ve üzeri & 18 & 3,679 & ,671 & & \\
\hline \multirow{4}{*}{ Toplam } & $1-5 \mathrm{yll}$ & 68 & 3,217 & 1,157 & \multirow{4}{*}{1,32} & \multirow{4}{*}{ 269 } \\
\hline & 6-10 yıl & 67 & 3,049 & 1,066 & & \\
\hline & 11-15 yıl & 25 & 2,846 & 1,196 & & \\
\hline & 16 ve üzeri & 18 & 3,451 & ,856 & & \\
\hline
\end{tabular}

Tablo 5 sonuçlarına göre öğretimi planlama ve uygulama boyutunda $f=1.37$, $p=.253$, öğrenci, meslektaş, yönetici, veli ve toplumla ilişkiler boyutunda $f=.1,17$, $p=.322$ ve toplamda $f=1.32, p=.269$ olarak tespit edilmiştir. Alt boyutlar ve toplamda, katıımcıların mesleki deneyim değişkenine göre anlamlı fark bulunmamıştır. 


\section{Tartışma ve Sonuç}

Araştırmamızda beden eğitimi ve spor öğretmenlerinin aldıkları hizmet öncesi eğitime ilişkin algılarının cinsiyet, mesleki deneyim ve mezuniyette tabi oldukları müfredat programına göre (2006 öncesi ve sonrası) farklılaşıp farklılaşmadığının ortaya çıkarılması amaçlanmıştır.

Yapılan analiz sonucunda beden eğitimi öğretmenlerinin hizmet öncesi almış oldukları eğitimin yeterliğine ilişkin algılarının orta düzeyde olduğu belirlenmiş, "Öğretimi planlama ve uygulama" alt boyutunda beden eğitimi öğretmenlerinin "Öğrenci, meslektaş, yönetici, veli ve toplumla ilişkiler" alt boyutuna göre algıları daha düşük düzeyde olduğu ortaya çıkmıştır. Cinsiyet değişkeninde beden eğitimi öğretmenlerinin hizmet öncesi yeterlik algıları erkeklerin $(x=3,15)$ kadınlara $(x=3,01)$ göre daha yüksek olsa da anlamlı bir farklılık göstermemektedir. Yapılan çalışmalar beden eğitimi öğretmenlerinin öz yeterlikleri artıkça dersin atmosferi, öğrenci memnuniyeti ve motivasyonu da olumlu şekilde etkilendiğini gösterirken (Pan, 2014; Tessier, Sarrazin ve Ntoumanis, 2010; Tschannen-Moran ve Hoy, 2001). Çalışmamızda beden eğitimi öğretmenlerinin daha çok "Öğretimi planlama ve uygulama" boyutunda problem yaşadıkları ortaya çıkmıştır. Bulca, Saçlı, Kangalgil ve Demirhan (2012), beden eğitimi öğretmenlerinin hizmet öncesi almış oldukları öğretmenlik meslek bilgisi derslerinin teorik olarak yeterli olmaması, MEB (Milli Eğitim Bakanlığı) beden eğitimi öğretim programıyla üniversite öğretmen yetiştirme programlarının paralellik göstermemesinden kaynaklandığını işaret etmektedir. Ayrıca öğretmenlerin hizmet öncesinde öğretmenlik mesleği için gerekli becerilere sahip olma noktasındaki algıları yüksek olsa da (Moseley, Reinke ve Bookout, 2003) sınıf yönetimi, disiplin problemleri, öğretim stratejileri noktasında kaygı duymaktadırlar (Liaw, 2009). Eğitim-öğretim deneyimi sırasında da öz yeterlik algıları önemli ölçüde düşebilmektedir (Moseley, Reinke ve Bookout, 2003). Liaw'a (2009) göre hizmet öncesi eğitimde bilgi ve teorileri pratiklerini geliştirebilecekleri ortamlar sağlanması elzemdir. Bu bağlamda öğretmenlerin hizmet öncesi dönemde almış oldukları staj gibi uygulama eğitimlerinin oldukça önemli olduğu ortaya çıkmaktadır (Martins, Costa ve Onofre, 2015; McKinney, Haberman, Stafford-Johnson ve Robinson, 2008). Hizmet öncesi daha çok pedagojik bilgiye odaklanma eğilimi (Liaw, 2009), öğrenci sayısının fazlalığı, öğretim elemanı yetersizliği, öğretim elemanlarının niteliği, mezun olan öğretmen adaylarının istihdam sorunları, öğretmenlik mesleğine bakış açısı gibi konularda birtakım problemler bulunmaktadır (Şendağ ve Gedik, 
2015). Azar (2003), öğretmenlerin hizmet öncesinde almış oldukları teorik bilgilerin kendilerine bir anlam ifade edebilmesi için öncesinde gerçek bir sınıf ortamını tecrübe etmeleri ve gereksinim duyacakları bilgi birikimlerle karşılaşmaları gerektiğini belirtmektedir. Beden eğitimi öğretmenleri öğretmenlik deneyimi ve uygulamaları konusunda mesleklerinin ilk yıllarında problem yaşamaktadırlar (Uğraş, Güllü ve Yücekaya, 2019; Uğraş, 2018) Beden eğitimi öğretmenlerinin nitelikli bir hizmet öncesi eğitim alamamaları meslek hayatlarında birbirini tetikleyen farklı sorunlara yol açması muhtemeldir (Ugras ve Sagin, 2019).

Araştırmada 2006 programı öncesinde mezun olan öğretmenler ile 2006 programı sonrasında mezun olan öğretmenler arasında hizmet öncesi eğitime ilişkin algılarında fark olmadığı belirlenmiştir. 1998 lisans programında \%65 olan alan bilgisi oranı 2006 lisans programında \%50'ye düşürülürken genel kültür oranı ise \%9'dan \%24'e çıkarılmıştır (akt. Uğraş ve Gülü, 2019). Küçükahmet'e (2007) göre 20062007 yılında uygulamaya geçen programların birçok tartışmalı noktası olduğu yönündedir. Namlı ve Temel'in (2019) çalışmasında öğretim elamanları ve beden eğitimi öğretmenleri lisans programının alan bilgisi derslerinde yer alan uygulama derslerinin ve stajın yeterli olmadığını, beden eğitimi alanına meslek bilgisi derslerinin uyarlanamadığını belirtmektedir. Uğraş ve Güllü'ye (2018) göre Beden eğitimi öğretmenlerinin MEB'e bağı okulların imkan ve şartlarına göre lisans eğitimi almamakta ve bazı noktalarda niteliksiz bir eğitime maruz kalmaktadır. Bu nedenle, ölçme ve değerlendirme, alan bilgisi, yıllık plan hazırlama, evrak ve dosyaların hazırlanmasında kendilerinin yetersiz hissetmektedirler (Uğraş, 2018). Kangalgil (2014) çalışmasında beden eğitimi öğretmenlerinin özel alan yeterliklerine yeterli düzeyde sahip olmadıklarını bunun sebeplerinden birinin de lisans eğitiminin yetersiz olmasından kaynaklanabileceğini belirtmiştir.

Beden eğitimi ve spor öğretmenlerinin hizmet öncesi eğitime ilişkin algıları mesleki deneyim değişkeninde anlamlı bir farklılık göstermemektedir. Çalışmamızda mesleğe yeni başlayan öğretmenlerle meslekte uzun yıllardır görev yapan öğretmenler arasında aldıkları hizmet öncesi eğitim algısının farklılaşmazken öğretimi planlama ve uygulama ile öğrenci, meslektaş, yönetici, veli ve toplumla ilişkiler boyutlarında yeterli bir eğitim aldıklarını düşünmektedirler. Literatürde ise öğretmen yeterliği ile farklı sonuçlar söz konusudur. Yapılan çalışmalarda öğretmenin meslekte geçirdiği süre artıkça yeterlik duygusunun azaldığı (Brouwers, Tomic ve Boluijt, 2011; Morris-Rothschild ve Brassard, 2006), meslekte geçirilen süre artıkça yeterlik 
duygusunun artığı (Palmer, Stough, Burdenski ve Gonzales, 2005; Wolters ve Daugherty, 2007) veya mesleki deneyim artıkça öğretmenlerin yeterlilik duygularının değişmediği yönünde çalışmalarda mevcuttur. (Kaya, 2019; Zee, Koomen, Jellesma, Geerlings ve de Jong, 2016; Yılmaz, Çokluk-Bökeoğlu, 2008).

Sonuç olarak, beden eğitimi ve spor öğretmenlerinin cinsiyet, mesleki deneyim ve mezuniyette tabi oldukları müfredat programı değişkeninde anlamlı bir fark ortaya çıkmamıştır. Ancak beden eğitimi ve spor öğretmenlerinin aldıkları hizmet öncesi eğitime ilişkin algılarının yüksek olmadığı ortaya çıkmıştır. Özellikle "Öğretimi planlama ve uygulama" alt boyutunda beden eğitimi öğretmenlerinin "Öğrenci, meslektaş, yönetici, veli ve toplumla ilişkiler" alt boyutuna göre algıları daha düşük düzeydedir. Elde edilen bu sonuçlar ışığında beden eğitimi ve spor öğretmenleri eğitim ortamının düzenlenmesi, materyal hazırlama, konu alanı ve öğretim programı bilgisi, öğretme ve öğrenme etkinliklerinin uygulanması sınıf yönetimi ve ölçme değerlendirme, noktasında almış oldukları eğitimi yeterli görmemektedir.

\section{Öneriler}

Beden eğitimi öğretmenlerinin almış oldukları eğitimin yeterli olmamasından dolayı (özellikle öğretimi planlama ve uygulama boyutu) öğretmenlere doğrudan deneyim kazanmaları için hizmet içi eğitim verilebilir çünkü hizmet içi eğitimler öğretmenlerin gelişimi için önemli bir fırsattır (Kosko ve Wilkins, 2009; Wight ve Buston, 2003). Beden eğitimi öğretmenleri hizmet öncesi almış oldukları eğitimle gittikleri okullarda benzer ortamları göremeyebilirler. Bu noktada lisans programı oluşturulurken MEB ile üniversiteler işbirliği içerisinde olmalı ihtiyaca uygun öğretmen yetiştirilmesinin sağlanmalıdır. Aynı zamanda teorik ile pratik, konu alanı ile konu alanının öğretimi arasında bir uyum ve denge olması elzemdir.

\section{Kaynaklar}

Aracı H. (2001). Lise Beden Eğitimi Ders Programları. Ankara: Nobel Yayın Dağıtım.

Azar A. (2003). Okul deneyimi ve öğretmenlik uygulaması derslerine iliksin görüşlerin yansımalari [The reflection about school experience and teaching practice courses]. Milli Eğitim Dergisi, 159, 181-194.

Balcı, A. (2018). Sosyal bilimlerde araştırma yöntem, teknik ve ilkeler. Pegem Atıf Indeksi, 001-398. 
Brouwers A, Tomic W, \&Boluijt H. (2011). Job demands, job control, social supportand self-efficacy beliefs as determinants of burn outamong physical education teachers. Europe's Journal of Psychology, 7(1), 17-39.

Bulca Y, Saçlı F, Kangalgil M, \& Demirhan G. (2012). Beden eğitimi öğretmenlerinin öğretmen yetiştirme programına ilişkin görüşleri. Eğitim ve Bilim Dergisi, 37(165), 81-92.

Demirhan G. (2003). Beden eğitimi öğretmenlerinin beden eğitimi ve spora ilişkin felsefi görüşleri. Spor Bilimler Dergisi, 13(2), 38-66.

Demirhan G, \& Açıkada C. (1997). Türkiye ve Avrupa ülkelerinde beden eğitimi öğretmeni yetiştiren bazı yükseköğretim kurumlarının öğrenci, öğretim elemanı ve dersler boyutuyla karşılaştırılması. Spor Bilimleri Dergisi, 8(2), 4-25.

Doğan S, \& Koçak, O. (2014). Okul yöneticilerinin sosyal iletişim becerileri ile öğretmenlerin motivasyon düzeyleri arasındaki ilişki. Kuram ve Uygulamada Eğitim Yönetimi, 20(2), 191-216.

Fernández-Balboa JM. (1997). Knowledge base in physical education teacher education: A proposal for a new era. Quest, 49(2), 161-181.

Friedman ED. (1983). The Pupils image of the physical education teacherand suggestions for changing attitudes in teacher training. International Journal of Physical Education, 20(2), 15-18.

Gökmen H. (1988). Gençlerin gelişmelerinde beden eğitiminin rolü. Ortaöğretim Kurumları Beden Eğitimi ve Sorunları, Türk Eğitim Derneği Yayınları, Ankara.

Hair JF, Black WC, Babin BJ, Anderson RE, \&Tatham RL. (2013). Multivariate Data Analysis: Pearson Education Limited.

Karasar N. (2012). Bilimsel araştırma yöntemi (23. Basım) Ankara: Nobel.

Kaya İ. (2019). Okul öncesi öğretmenlerinin öz yeterlik inançlarının bazı değişkenlere göre incelenmesi. OPUS Uluslararası Toplum Araştırmaları Dergisi, 11(18), 345-363.

Kosko KW, \&Wilkins JL. (2009). General Educators' In-Service Training andTheir Self-Perceived Ability to Adapt Instruction for Students with IEPs. Professional Educator, 33(2).

Küçükahmet L. (2006). 2006-2007 Öğretim yılında uygulamaya başlanan öğretmen yetiştirme lisans programlarının değerlendirilmesi. Türk Eğitim Bilimleri Dergisi, 5(2), 203-219. 
Sağın AE, Karabulut Ö. (2020). Beden Eğitimi ve Spor Öğretmenlerinin Aldıkları Hizmet Öncesi Eğitime İlişkin Algılarının Belirlenmesi. Gaziantep Üniversitesi Spor Bilimleri Dergisi, 5(2), 121-133.

Liaw EC. (2009). Teacher efficacy of pre-service teachers in Taiwan: The influence of classroom teaching and group discussions. Teaching and Teacher Education, 25(1), 176-180.

Lim CP, Cock K, Lock G. ve Brock G. (2009). Innovative practices in pre-service teacher education: An Asia-pasific perspective. The Netherlands: Sense Publishers.

Martins M, Costa J, \&Onofre M. (2015). Practicum experiences as sources of preservice teachers' self-efficacy. European Journal of Teacher Education, 38(2), 263-279.

McKinney SE, Haberman M, Stafford-Johnson D \& Robinson J. (2008). Developing teachers for high-poverty schools. Urban Education, 43, 68-82.

Morris-Rothschild BK, \&Brassard MR. (2006). Teachers' conflict management styles: The role of attachment styles and classroom management efficacy. Journal of school psychology, 44(2), 105-121.

Moseley C, Reinke K, \&Bookout V. (2003). The effect of teaching out door environmental education on elementary preservice teachers' selfefficacy. Journal of Elementary Science Education, 15(1), 1-14.

Namlı AK, \& Temel C. (2019). Beden eğitimi ve spor öğretmenliği lisans programının değerlendirilmesi ve program önerisi. Milli Eğitim Dergisi, 48(1), 321-351.

Nebioğlu D. (2006). Beden Eğitimi Dersinde Örnek Uygulamalar. Ankara: Nobel Yayın Dağıtım.

Palmer DJ, Stough LM, Burdenski Jr, TK., \&Gonzales M. (2005). Identifying teacher expertise: An examination of researchers' decision making. Educational Psychologist, 40(1), 13-25.

Pan YH. (2014). Relation ships among teachers' self-efficacyand students' motivation, atmosphere, andsatisfaction in physical education. Journal of Teaching in Physical Education, 33(1), 68-92.

Senemoğlu N. (1990). Öğretmen adaylarına 'genel kültür' kazandırma bakımından fen-edebiyat ve eğitim fakültelerinin etkililiği. Çağdaş Eğitim Dergisi.

Siedentop D. (2002). Content knowledge for physical education. Journal of teaching in physical education, 21(4), 368-77.

Şendağ S, \& Gedik N. (2015). Yükseköğretim dönüşümünün eşiğinde Türkiye'de öğretmen yetiştirme sorunları: Bir model önerisi. Eğitim Teknolojisi Kuram ve Uygulama, 5(1), 70-91. 
Tabachnick BG, Fidell LS, \&Ullman JB. (2013). Using multivariatestatistics (Vol. 6). Boston, MA: Pearson.

Tessier D, Sarrazin P, \& Ntoumanis N. (2010). The effect of an intervention to improve newly qualified teachers' inter personal style, students motivation and psychological need satisfaction in sport-based physical education. Contemporary Educational Psychology, 35(4), 242-253.

Tschannen-Moran M, \& Hoy AW. (2001). Teacher efficacy: Capturing an elusive construct. Teaching and teacher education, 17(7), 783-805.

Uğraş S. (2018). Beden Eğitimi Öğretmenleri Kendilerini Hangi Konularda Yetersiz Hissediyor? Çanakkale On sekiz Mart Üniversitesi Spor Bilimleri Dergisi, 1(1), $1-16$.

Uğraş S, Güllü M, Yücekaya M. (2019). Beden eğitimi ve spor öğretmenliğindeki ilk yılım. Eğitimde Nitel Araştırmalar Dergisi, 7(1), 242-259. Retrieved from http://dergipark.org.tr/en/pub/enad/issue/43049/521541

Uğraş S, \& Güllü M. (2019). Beden eğitimi öğretmenliği bölümlerinin yeterliliği ile ilgili öğretmen görüşleri. Anemon Muş Alparslan Üniversitesi Sosyal Bilimler Dergisi, 7(2), 57-65.

Ugras S, \& Sagin AE. (2019). Why Do Physical Education Teachers Give High Grades? Educational Policy Analysis and Strategic Research, 14(4), 256-269.

Wight D, \& Buston K. (2003). Meeting needs but not changinggoals: evaluation of inservice teacher training for sexeducation. Oxford Review of Education, 29(4), 521-543.

Wolters CA, \& Daugherty SG. (2007). Goal structures and teachers' sense of efficacy:Their relation and association to teaching experience and academic level. Journal of educational psychology, 99(1), 181.

Yılmaz K, \& Çokluk-Bökeoğlu Ö. (2008). İlköğretim okulu öğretmenlerinin yeterlik inançları. Ankara Üniversitesi Eğitim Bilimleri Fakültesi Dergisi, 41(2), 143167.

Zee M, Koomen HM, Jellesma FC, Geerlings J \& De Jong PF. (2016). Inter-and intraindividual differences in teachers' self-efficacy: A multi level factor exploration. Journal of School Psychology, 55, 39-56.

Kangalgil M. (2014). Beden eğitimi öğretmenlerinin özel alan yeterliklerine katılma ve sahip oluş derecelerinin incelenmesi. Spor Bilimleri Dergisi, 25(2), 94-103. 
Sağın AE, Karabulut Ö. (2020). Beden Eğitimi ve Spor Öğretmenlerinin Aldıkları Hizmet Öncesi Eğitime İlişkin Algılarının Belirlenmesi. Gaziantep Üniversitesi Spor Bilimleri Dergisi, 5(2), 121-133.

Kozikoğlu I, \& Senemoğlu N. (2018). Hizmet Öncesi Eğitimin Yeterliğine IIlişkin Öğretmen Algı Ölçeğinin Geliştirilmesi: Geçerlik ve Güvenirlik Çalışması. Yüzüncü Yıl Üniversitesi Eğitim Fakültesi Dergisi, 15(1), 552-576. 